\title{
Education Response to the World of Work in the Knowledge Society
}

\author{
Aleksandra Pejatović, ${ }^{1}$ Miomir Despotović ${ }^{2}$
}

\section{Introduction}

The European Union's determination to establish its development on knowledge, education, lifelong and life-wide learning is evident in many documents created over the last two decades. In A Memorandum on Lifelong Learning, promoted by the European Commission, the age we live in has been compared to the Industrial Revolution period due to the number and intensity of changes. Lifelong learning is, in this context, seen as a necessary companion in a successful transition to a knowledgebased economy and society, while at the same time representing "an essential policy for the development of citizenship, social cohesion and employment". 3

Knowledge-based economy is central to the strategic goal towards which the development of Europe was directed at the start of the first decade of the XXI century. That goal is to make Europe "become the most dynamic and competitive knowledge-based economy at the world, capable of sustainable economic growth with more and better jobs and greater social cohesion, and respect for the environment". ${ }^{4}$ Europe, characterized by the above-mentioned features, is certainly in need of a

\footnotetext{
1 Department for Pedagogy and Andragogy, Faculty of Philosophy University of Belgrade, Serbia.

2 Department for Pedagogy and Andragogy, Faculty of Philosophy University of Belgrade, Serbia.

3 A Memorandum on Lifelong Learning (Brussels: Commission of the European Communities, 2000), 6.

4 The Lisbon Strategy 2000-2010, An analysis an evaluation of the methods used and results achieved (Brussels: European Parliament, 2010), 11.
} 
population capable of reaching, supporting and directing the projected developmental path towards the next stage of development. It is therefore recommended that within "skills ecosystems" individuals' skills be raised to a level that will help to " "get in' (to work in the first place, from education or from unemployment), 'stay in' (keep in work after entering the labour market) and 'get on' (progress through the labour market into better jobs)". ${ }^{5}$ Although learning and skills developed by learning are, as we can notice in all mentioned documents, predominantly linked to the world of work (with the capacity for active citizenship, achieving social cohesion and developing a responsible attitude to the environment), they do not only refer to professional skills, but also to the needed set of soft or transferable skills, or key competences necessary for the population in all spheres of life. The reference books include: communication in the mother tongue and communication in foreign languages, mathematical competence and basic competences in science and technology, digital competence, learning to learn, social and civic competences, sense of initiative and entrepreneurship, cultural awareness and expression ${ }^{6}$ and other competences/skills. Drawing attention to the need to develop the set of necessary general and professional competences for life in modern society means at the same time providing guidance on which outcomes (knowledge, skills, attitudes) and contents education and learning should be concentrated.

Another example of highlighting the importance and the role of education and lifelong learning can be found among the Sustainable Development Goals - SDGs (Global Goals), promoted in 2015, within Education 2030: Incheon Declaration and Framework for Action...7 , by the UNESCO and several international organisations. Along with the view that education is " ...at the heart of the 2030 Agenda Sustainable Development and essential for the success of all SDGs" SDGs is dedicated to education and it reads as follows: "Ensure inclusive and equitable quality education and promote lifelong learning

\footnotetext{
5 New Skills for New Jobs: Action Now (Brussels: European Commission, 2010), 10.

${ }^{6}$ Key Competences for Lifelong Learning - European Reference Framework (Luxembourg: Office for Official Publications of the European Communities, 2007).

7 Education 2030: Incheon Declaration and Framework for Action for the implementation of Sustainable Development Goal 4: Ensure inclusive and equitable quality education and promote lifelong learning (UNESDOC Digital Library, 2016) https://unesdoc.unesco.org/ark:/48223 /pf0000245656 (accessed December 2, 2019).

8 Education 2030, 24.
} 
opportunities for all". ${ }^{9}$ It is evident that education and lifelong learning have been given the status of a necessary and inseparable companion of human society. It is therefore extremely important to provide the population with a broad access to lifelong learning opportunities.

Looking at the history of human society development through the change of different production systems, on one hand, education has always responded to the needs for training and development of the necessary staff, while on the other hand, by playing its role, it has contributed to further development of both production systems and society as a whole. If we were to agree that today we globally live in the world that can be characterized as a knowledge society or the world that strives to be a knowledge society, then its part we call "world of work" would actually be the "knowledge-based world of work" and as such it would possess certain characteristics. This would mean, among other things, that it is the world of work whose foothold is in education and learning. The aim of this paper has been set on the relation between the world of work and the world of education with the intention of analysing what demands the world of work makes to the world of education and how the world of education responds to the needs identified. The context in which this relation and exchange happen would represent a knowledge society. We have identified the demands of the world of work by taking into consideration some of its basic characteristics today.

We thought it would be necessary to start the analysis by considering the concept of "knowledge society" and its related and supporting concepts.

\section{The concept of "knowledge society" and related concepts}

The term "knowledge society" is attributed to Peter Drucker who, back in the 1950s, drew attention to the fact that knowledge is becoming a significant resource today. "The modern market economy is a business world in which individuals and organisations can survive only if they possess certain kind of knowledge and skills... It can be understood as means to accomplishing social and economic results". ${ }^{10}$ A knowledge

\footnotetext{
${ }^{9}$ Ibidem, 22.

10 M. Kovacevic, N. Pavlovic, "Globalization and the Knowledge Society," Ekonomika 62:4 (2016): 85-94.
} 
society needs "knowledge workers", who must possess a set of knowledge and skills developed up to the "advanced level of expertise". ${ }^{11}$

In order to clarify the concept of "learning society", Peter Jarvis takes into consideration its four dimensions. As a matter of fact, we consider the terms "knowledge society" and "learning society" synonymous; however, in the first case, society is designated as a product of learning knowledge, and in the second case as a process of knowledge acquisition - learning. The four dimensions of "learning society" which Jarvis lists are: vision, planning, reflexivity and market. Based on the vision, a "learning society" is viewed and projected as a "good society", "which is both democratic and egalitarian; a society in which individuals can fulfil their potentials through education and lifelong learning - which is something the school has prepared them for". ${ }^{12}$

The dimension planning refers to the strategies for developing a "learning society" which have been outlined in many European documents. In them, the emphasis is on the importance of lifelong learning for employment, employability, economic development, democracy development and other expected effects of learning, both individually and socially. It is also stated that both education and learning take on some different characteristics precisely because of their focus on the above listed effects. We have mentioned some of these documents in the introductory part of this paper.

Reflexivity as a dimension stems from one of the essential characteristics of a "learning society", which is that riskiness is linked to it. It stems from the complexity of modern society in which every decision-making is riddled with risk, as it is usually about choosing one or some of the alternative solutions rather than giving a one-sided answer. As Jarvis points out, decision-making is a driver of thinking, deciding, reviewing and analysing the effects of the decisions made, which is all a learning process. Another characteristic of learning in this way is criticality, not only in relation to the decisions made, but also to what has been learned. ${ }^{13}$ Considering reflexivity, as one of the dimensions of the "learning society", leads us to realize that in this society learning opportunities are widely spread throughout people's

\footnotetext{
11 Z. Avramovic, according to M. Kovacevic, N. Pavlovic, "Globalization...".

12 P. Jarvis, "Poučavanje u svijetu koji se menja" [Teaching in a changing world], in Poućavanje [Teaching], ed. Peter Jarvis (Zagreb: Andragoški centar, 2003), 23-36.

13 Ibidem, 30-31.
} 
lives and that they have come out of the once dominant school solely responsible for teaching and learning. As noted, in the "learning society", learning that happens in communication with other people is to a lesser extent institutionalized and controlled. This time, too, we get to numerous learning opportunities as one of the characteristics of the "knowledge society".

The fourth dimension - the market, indicates that both education and learning are related to the market in the sense that, as Jarvis thinks, education is related to producers as it is something that is delivered, while learning is related to consumers as it is something that is consumed. Given that characteristics of the "learning society" certainly change the context in which education and learning take place, so do the understandings of teaching and learning. A lot can be learned in many ways; teaching is increasingly becoming an exchange, since situations are not rare when the one who is learning may know more about the relevant topic than the one who is teaching. Applicable, rational, empirical and pragmatic knowledge is sought for. ${ }^{14}$ Knowledge is generated through communication and it is solidified by experience and the learned needs to be re-expressed in communication and to contribute to the creation of a new experience.

Although much has been written about the "knowledge society", with starting points from different scientific disciplines, it still seems that this concept has not been unambiguous and yet further elaborated. On the basis of the analyses conducted, Jarvis identifies three meanings of the syntagm "learning society". He relates the first meaning to the ideal "of a new moral and politically democratic society". ${ }^{15}$ The second meaning refers to the society which represents reality, which is characterized by rapid changes; education, however, is not emphasized as particularly important for its creation. And the third meaning refers to the existing consumer society where "education has become a commodity to be sold in the market place, with other learning packages... Consequently, the learning mode has become part of the lifestyle...". ${ }^{16}$ The three meanings mentioned here raise, in fact, two concerns. The first concern is whether

\footnotetext{
14 Ibidem, 31-34.

15 P. Jarvis, "The Learning Society," in Glossary of Adult Learning in Europe, ed. Paolo Federighi, Willem Bax, Lucien Bosselaers (Hamburg: EAEA and UNESCO Institute for Education, 1990), 21-22.

16 P. Jarvis, "The Learning Society," 21-22.
} 
the "knowledge society" is an ideal to strive for or whether it is the real existing society of which we are members. The second concern refers to the contribution of education and learning to the establishment and development of the "knowledge society". The question arises as to whether education and learning are of not excessive importance or of utmost importance. We are not sure, seemingly, which part of the path we are on while heading towards the "knowledge society"; we are also not sure whether learning and knowledge are crucial along the way, as well as whether we have created the pre-conditions for education and learning that lead to a better society.

One of the corresponding concepts to the "knowledge society" is the concept of a "learning organisation". By analysing the literature which explains this concept, we have come to the conclusion that a learning organisation can be understood as "an organisation which has systems, mechanisms and processes, that is, an organisational infrastructure for improvement and development of its members, in the function of achieving organisational goals and the goals of the community in which the organisation operates". ${ }^{17}$ It means that the organisation does not only survive, but it also develops and transforms itself with the help of learning. Learning effects are visible at the level of individuals operating within the organisation, at the level of individual sectors and organisation as a whole, as well as at the level of community (immediate and possibly wider) in which the organisation carries out its activities.

As essential characteristics of the "learning organisation" we can mark the following: the ability to adapt to external circumstances; the developed sense of personal and collective responsibility for the functioning and successful business operation of the organisation; understanding changes as the only stable organisational state; considering individual and collective mistakes and success as crucial components of learning; the development of a participatory culture with an atmosphere of mutual respect and trust; the ability to identify and analyse problems in order to find relevant solutions; and others. ${ }^{18}$ It is obvious that the concept of "learning organisation", as well as the concepts of "knowledge workers" and "knowledge society", bring with them many new qualities, in terms of characteristics, to the people who need to live

${ }_{17}$ R. Kulić, M. Despotović, Uvod u andragogiju [Introduction to Andragogy] (Beograd: Svet knjige, 2004), 106.

18 R. Kulić, M. Despotović, Uvod u andragogiju, 106. 
within them, work and belong to the category labelled as "knowledge workers". Among those characteristics are surely the development of certain competences, responsibilities and independence as well as a high degree of activity. The development of these, among other things, key personality traits can be seen as the needs modern society poses to education and training.

Along with the already analysed concepts, the following appear in the reference literature as similar to them: "learning communities", "learning cities" and "learning regions". On this occasion, we will analyse more the term "learning cities". In the UNESCO documents, "learning cities" are defined as "a city which effectively mobilizes its resources in every sector to promote inclusive learning from basic to higher education; revitalize learning in families and communities; facilitate learning for and in the workplace; extend the use of modern learning technologies; enhance quality and excellence in learning and foster a culture of learning throughout life. In so doing it will create and reinforce individual empowerment and social cohesion, economic and cultural prosperity, and sustainable development." 19 "Learning cities" would, by that definition, be cities which repeatedly support learning, thus creating opportunities for it to happen throughout the lives of the individuals who live in them. This omnipresent learning leads to the development of individuals, their communities, organisations, cities and society.

Based on this concise analysis, it is evident that the concepts covered are complementary and that they constitute a distinctive matrix for understanding modern society and for life in it. Learning and/or knowledge, which are part of each of the syntagms, clearly point to the importance attributed to them for the development of the "knowledge society". We have already emphasised that there is an interdependence between learning and the development of society (individual, organisation), that is, just as learning contributes to the development of society by creating its certain characteristics, the society transforms through its development, while also acquiring some (relatively) new qualities. In the section that follows, we will focus on the response of education to the needs of the world of work in the "knowledge society".

19 UNESCO Global Network of Learning Cities: guiding documents (Hamburg: UNESCO Institute for Lifelong Learning 2015), 9. 


\section{Education and training and needs of the world of work in the "knowledge society"}

The emergence of modern characteristics of learning, education and training processes can be, among other things, linked to their meeting the needs of the world of work for workforce in the "knowledge society". In this regard, meeting the needs leads to changes in learning, education and training processes, as well as to changes in the world of work which are characterised as very fast and not rarely as drastic, too. We have placed the analyisis of changes related to education and training within the following relations: contemporary global characteristics of the world of work - phenomena in the world of work which occured as a result of reflecting global characteristics of the world of work - responses of education and training to the phenomena occurred.

For the purposes of our earlier research study, based on the literature consulted, we have identified 28 characteristics of the modern world of work. ${ }^{20}$ In this article, we will analyse some of them (mainly the most frequently cited and discussed) which are directly related to some of the most significant changes in the fields of (adult) education and training, typical of the "knowledge society".

One of the two inevitable characteristics of the world we live in, as well as of the world of work, is surely globalisation. Among the phenomena in the field of work influenced by this characteristic are: creation of one global economy; reflection, to the level of consequences, of the events in some part of the world to the other (distant) parts of the world; a high economic interdependence; global connectivity of markets operating 24 hours a day; dominance of remote jobs; emergence of new stakeholders in the global economic life such as multinational companies, internationally developed networks of NGOs and the like; establishment of a number of international standards related to various elements and aspects of work and workforce; new requirements regarding necessary competences of all employees, in particular the management staff (such as cultural awareness, adaptability and others); operations of companies in several markets (relocation of part of business to other countries, purchase of goods produced in other markets, placement of own

20 A. Pejatović, V. Orlović Lovren, Zaposlenost i obrazovanje posle pedesete [Employment and Education after Fifty] (Beograd: Institut za pedagogiju i andragogiju Filozofskog fakulteta Univerziteta u Beogradu, Društvo andragoga Srbije, 2014), 51-57. 
products in foreign markets, relocating own employees abroad, employment of foreign workforce)... The initiated series is not complete, of course, but our intention is to draw attention to some, for this paper relevant, phenomena that globalisation has led to and that simultaneously account for it.

The question that is raised here, which we are particularly interested in, is in what way education and training keep pace with the phenomena listed and how, by surely transforming themselves, they meet educational needs arising from these phenomena.

What first comes to mind would be changes in the contents of education and training. When it comes to adult training, two distinct but complementary trends are noticeable. On the one hand, it is evident that trainings are becoming highly specialised, i.e, that there are more and more trainings aimed at training for performing highly professional job segments. On the other hand, in parallel with the trainings mentioned, there is an increase in the number of trainings whose outcomes are aimed at mastering general but work-relevant compentences such as: problem solving, maintaining good interpersonal relations at work, team work, communication with clients, conflict resolution, safety at work, overcoming negative effects of work, numeracy, emotional stability, change management and others. ${ }^{21}$

However, acquiring specific contents does not just mean acquiring knowledge; it rather seems that emphasis today is, to a larger extent, placed on the development of competences. Putting competences in the focus of education and training sets to these processes, in addition to acquiring knowledge, not at all easy requirements for the development of specified sets of skills, abilities, personality traits, attitudes and values. It means that besides knowing something, a person has to be able to perform specified, relatively complex tasks, to do them in line with specific standards (which would mean doing it properly) and to behave in a manner defined as desirable in the working environment. To know, to be able to and to behave), that is, to be competent in the context of the modern world of work means that people "understand the environment and totality of the production process, to efficiently act in various and unpredictable situations, to go through different functions

21 A. Pejatović, Obuka za odrasle - susret očekivanja i procenjivanja [Adult training - The Encounter of Expectations and Evaluations] (Beograd: Institut za pedagogiju i andragogiju Filozofskog fakulteta Univerziteta u Beogradu, 2019), 41-51. 
and organisational units while doing the job, to work with other people, to learn from others, to make decisions and to solve problems". ${ }^{22}$ Efforts to develop, in addition to knowledge, some other elements of competences, as well as sets of competences within the processes of education and training, have led to a more frequent use of various interactive techniques and methods such as: role play, simulations, demonstrations, project-based teaching, problem solving, discussions, presentation making, team work, small group work and many others.

Changes in the contents of education and training, in particular the increasing prevalence of interactive techniques, methods and forms of work, have had a significant impact on changes in the roles of teachers or trainers and participants in the programmes. The teacher and/or trainer now necessarily change the roles during the teaching process as needed, by being: trainers and presenters, as well as coaches, or facilitators, moderators, mentors... Participants' meaningful activity should now be central to teaching with the purpose of encouraging the learning process. The changed roles of the participants in the processes are also reflected in the communication established between them during the process of teaching/learning.

Representation of education and training aimed at competence development has established yet another of the main characteristics of modern vocational education and training systems, which is their focus on outcomes formulated in terms of competences. Orientation to outcomes is one of the approaches in curriculum development. "In the field of vocational education outcomes enable "production" of professionals, that is, competences, in which the nature of the final "product" is totally clearly defined. It is the orientation to the end result, attributes and performances that have to be "brought out" from the situation and the learning process". ${ }^{23}$ Consequently, outcomes are formulated on the basis of the conducted job analysis already in the initial stages of designing an educational or training programme, that is, knowledge, skills and attitudes participants should have upon successful completion of the programme are clearly specified. Outcomes should be known and clear to all stakeholders interested in implementing the

22 B. Mansfield, L. Mitchell, 1996, according to M. Despotović, Razvoj kurikuluma u stručnom obrazovanju [Curriculum Development in Vocational Education] (Beograd: Filozofski fakultet Univerziteta u Beogradu, 2010), 128-129.

23 M. Despotović, Razvoj kurikuluma, 94. 
programme: programme implementers, participants, financiers, managers in the organisations where the learned should be applied and to others. Outcomes must be measurable in order to monitor the development of competences as well as in order to assess participants' achievements. Programmes are presented by outcomes, and also, in vocational education they are the main elements on the basis of which education and learning programmes are accredited, which should be special confirmation of their quality.

By mentioning accreditation, we refer, among other things, to the subject of standards in education and training. We have already mentioned standardisation in the field of work when referring to the phenomena in the world of work created under the influence of the globalisation process. One of the most important functions of international standards, in the field of education and training and in other fields, is to enable the recognition and translation of achievements in the labour and education markets in different countries and regions of the World. This type of standards refers to all elements of the education and training systems, such as achievements of participants, teaching and training staff, of work of the institutions in which the educational process and/or processes of training, educational and training programmes and others are implemented. For example, some of the international standards which refer to education and training are: European Qualification Framework (EQF) which serves as a reference framework for identification and translation of qualification levels in the European area; European Credit System for Vocational Education and Training (ECVET); European Quality Assurance Reference Framework for Vocational Education and Training (EQARF); European Credit Transfer and Accumulation System (ECTS) in the field of higher education, which should facilitate student mobility between different countries; ISO 29990:2010, Learning services for non-formal education and training - Basic requirements for service providers; ISO 10015:1999(E), Quality management - Guidelines for training; and others.

Standards which refer to outcomes in competences, classified by qualification levels, open up opportunities for adults of different ages to qualify through the formal education system, then through the nonformal system and through the process of recognition of prior learning, that is, of what has been learned informally. As already stated for modern 
education and training systems, the emphasis is on the result, i.e., on what should be the result of teaching and/or learning process in the form of knowledge, skills and attitudes. The way in which knowledge, skills and attitudes have been acquired, that is, in which competences have been developed, remains in the background if an individual meets the standard of a particular qualification. One of the basic characteristics of the knowledge society, which is creating and recognising numerous lifelong learning opportunities, is thus supported, while through qualification frameworks opportunities are opened up for certifying, that is, for recognising, in various ways, what has been learned.

The second of the two most commonly cited characteristics of the modern world of work which contributes to a significant expansion of learning opportunities is the breakthrough of information and communication technologies (ICT). We could say that ICT is the most responsible for a tremendous increase in the availability of education and training to members of all generations. Some of the phenomena which occurred under the impact of the ICT expansion in the processes of work, working environment and organisation include: emergence and development of many new occupations; changes in job descriptions within the already existing occupations; modification of work modes; acceleration of work processes; creation of virtual teams as well as other economic, organisational, social processes and forms (e-commerce, e-banking and the like); management staff loses the monopoly over information in comparison to other employees; change of work place (for instance, work from home); emergence of various, more flexible forms of workforce engagement... ${ }^{24}$

According to EUROSTAT data "The number of persons employed as ICT specialists grew by $40.0 \%$ during the period from 2011 to 2019 , which was slightly less than 6 times as high as the corresponding increase $(6.9 \%)$ for total employment". ${ }^{25}$

Again, as in the case of globalisation, a series of the listed phenomena refers us to the emergence of a real abundance of new educational contents and training contents. In relation to ICT, new contents are on the continuum from key competences (digital competence, information

\footnotetext{
24 A. Pejatović, Obuka za odrasle, 40-51.

${ }^{25}$ ICT specialists in employment (Eurostat, 2020), https:/ / ec.europa.eu/eurostat/statisticsexplained/index.php/ICT_specialists_in_employment\#General_developments_in_the _demand_for_ICT_specialists (accessed November 06, 2020).
} 
literacy, media literacy...) to narrowly specialised competences in order to master a specific occupation or carry out parts of the job in a wide variety of occupations related to the use of ICT. It is the ICT sector in which the greatest number of new occupations and jobs has occurred in the last decades.

In addition to availability of learning opportunities and new learning contents, ICT has contributed to the creation of many new types of teaching and training such as: blended learning, distance learning, elearning, online learning, Internet-based training, intranet-based training, multimedia training, computer-based training, video-tele training, webbased training, combined forms of teaching with ICT support (the socalled "hybrid transmission") and others. ${ }^{26}$ Given that teaching and training are complex systems which consist of more elements, within the listed and their similar types it is not only the way in which the content is delivered, but also the changes that occur in regard to ways of teaching, methods, techniques, teaching materials, roles of actors in the teaching process and their mutual communication, ways of assessing what has been learned...It means that the changes have affected the entire teaching cycle as well as the training cycle, from initial stages of planning and programming to evaluation of students' and participants' achievements.

And this concise listing of changes that continuously happen in the field of education and training as a result of education and training meeting the needs of the world of work leads to the conclusion that the breakthrough of ICT has caused highly significant changes in education and training systems. Those changes also involve certain characteristics (qualities) of these systems as is availability, for example, and they include the entire teaching process and training process, not only in the part of direct implementation but entire cycles - from design to evaluation, with all stages within them.

One of the characteristics of the modern world of work is the increasing importance of human capital. This characteristic points to the emergence of identification and recognition of human capital as the most important form of all other forms of capital such as finance, equipment, facilities...In global competition and competition between companies, human capital takes the primary place. As Raymond Noe states, human

26 A. Pejatović, Obuka za odrasle, 40-51. 
capital "refers to the sum of the attributes, life experiences, knowledge, inventiveness, energy, and enthusiasm that the company's employees invest in their work." 27 In fact, employees need to incorporate in their work all they have learned, that is, what they know and can do, their abilities, traits and values that they have developed and that are relevant to their work and the organisation in which they work. Learning, education and training have a direct impact on human capital development, thus transferring the importance attributed to human capital in the world of work to education and training.

What significantly defines today the environment in which an individual works in an organisation is yet another characteristic of the world of work, called workplace diversity. It refers to many diversities which today characterise employees in the organisation. Although they are in the same "place" while working every day, they differ from each other by: gender; age, that is, life stages in which they are; education; work experience; career development; ethnicity; religion; political affiliation; sexual orientation; relevant abilities, motivation for work and many other characteristics. ${ }^{28}$ Since both employed and unemployed have to develop continuously in order to remain competitive in the labour market, different target groups of participants enter education and training. For example, trainings are organised for: newly employed young workers, senior workers, women, national minorities, migrants, people with special needs, for attracting and retaining talented staff, getting used to retirement...In this way, the diversity which exists at workplace is achieved in education and training. Groups of users of organised learning opportunities are different; each of the groups searches for programmes that meet their current (educational) needs. Heterogeneity of the educational group is, among other things, typical of education and training in adulthood.

In addition to the fact that education has been "entered" by participants who are characterised by many differences, including those who previously were not keen on being involved in the educational process or training process in adulthood, workplace diversity has brought another, new type of training, called "diversity training", which is aimed

${ }^{27}$ L. Weatherly, 2003, according to R. Noe, Employee Training and Development (New York: McGraw-Hill Irwin, 2010), 13-14.

28 S. E. Jackson, A. Joshi, 2001, according to: J. Arnold at al., Work Psychology: Understanding Human Behaviour in the Workplace (Harlow: Prentice Hall, 2005), 35. 
at changing employees' attitudes towards diversity as well as at developing the skills needed to work in the environment characterised by diversity. ${ }^{29}$

Workplace diversity is closely linked to two more characteristics of the modern world of work, namely: ageing of employees and increasing economic activity of women. These two characteristics certainly add to diversity in organisations.

Although we have so far mostly talked about characteristics of the world of work which are most visible at the company level, we cannot disregard unemployment as one more characteristic of the world of work today. "Eurostat estimates that 15.990 million men and women in the EU-27... were unemployed in September 2020... Compared with September 2019, unemployment rose by 1.811 million in the EU..." 30 Unemployment, which can be of a different nature according to its causes of origin (frictional, structural, stagnant, technological, etc.), characterises many economies of the world today. In order to solve this very complex issue, sets of active labour market measures have been developed and they are undertaken in order to solve, or at least, mitigate this issue. Among these active measures, education and training intended for different categories of unemployed and potentially unemployed take a significant place. Within these measures, the following occur as predominantly educational by nature: completion of functional elementary education in adulthood with the training for the first, simple, occupation; training for active job seeking; training for overcoming the stress of losing a job; training for entrepreneurship development; professional practice programmes; internship programmes; programmes for acquiring practical knowledge for the unskilled, redundant and longterm unemployed; labour market training; specialised IT training; training for the unemployed at the request of employers... ${ }^{31}$ As we can see, based on the programmes within the measures, they are aimed at increasing employability or at employing a very heterogeneous population of the

\footnotetext{
${ }^{29}$ R. Noe, Employee Training and Development, 552.

30 Unemployment in the EU and the euro area (Eurostat, 2020), https://ec.europa.eu/ eurostat/statistics-explained/index.php/Unemployment_statistics\#Unemployment_in_ the_EU_and_the_euro_area (accessed November 06, 2020).

31 Nacionalni akcioni plan zapošljavanja za 2019. godinu [2019 National Employment Action Plan] (Beograd: Ministarstvo za rad, zapošljavanje, boračka i socijalna pitanja; Tim za socijalno uključivanje i smanjenje siromaštva, 2018), 45-47.
} 
unemployed. In this case, education and training appear in order to solve one of the life problems of the members of this category of population, the problem which often occurs coupled with a series of other problems.

In response to job insecurity in modern society, the concept of flexicurity has been brought to life in countries with highly developed economies. In fact, when looking at the characteristics of the world of work, it is about changing the concept of security and developing the concept of flexicurity. The change of the concept of security signifies re-orientation in the understanding of job-related security, from security on a job (which has certainly not lost its significance) to job security, that is, security to keep the job. The flexicurity concept, that is, the strategies developed on the basis of this concept, consists of four sub-systems: 1) flexible and reliable work contracts; 2) life-long learning; 3) active labour market policy; and 4) a developed social security system (especially in case of unemployment). ${ }^{32}$ Within this concept we also notice the necessity of lifelong learning in order to make it sustainable and in order to reach necessary flexibility, which means an easy transition from one job to the other, or keeping a job despite various changes and an easier transition from unemployment to employment.

Some of the characteristics of the modern world of work which we have mentioned last practically direct us to one of the relevant changes, the one that refers to the change of the career concept. The contemporary understanding of career is characterised by putting emphasis on career development which is connected to each individual and which is specific to each individual. While pointing out that there is no complete agreement when defining a career, Arnold et al. define it as "the sequence of employment-related positions, roles, activities and experiences encountered by a person" ". 33 The sequence is used here in the meaning "more than one" and as the authors further emphasise "Instead of looking at a person's present job in isolation, we are interested in how it relates to his or her past and future". ${ }^{34}$ Placing the currently taken position - sequence in the context of what preceded that position as well as what should be the next sequence on the basis of what has been

32 A. Pejatović, T. Kunić, "Obrazovanje odraslih kao faktor ostvarivanja koncepta fleksigurnosti" [Adult education as a factor in realizing (implementing) the concept of flexicurity], Obrazovanje odraslih 2 (2012): 9.

$33 \mathrm{~J}$. Arnold at al., Work Psychology, 520.

34 Ibidem. 
previously achieved and the current position, is, in fact, placing the current position in the context of a person's career development. Between the sequences that preceded and the sequences that should constitute the next stages of development an important place belongs to education and training, that is, learning. Today we talk about competences a person should master in order to manage own career development. The areas covered by this type of competences include, for example: discovering and understanding oneself; considering the opportunities of the world of education and the world of work; and creating one's own career. ${ }^{35}$ In order to develop the mentioned segments of the career management competence, standards of competences of practitioners who deal with lifelong career guidance and counselling, organisational standards for institutions which provide career guidance and counselling services and standards of training programmes for the development of career management skills have been adopted. ${ }^{36}$

The analysed interrelations of the characteristics of the modern world of work, phenomena which occurred under the impact of some of the characteristics selected for this occasion and the response of the world of education and training to the newly created needs, have led to significant changes in the work-related and professional sphere of man's life as well as in the process of his career development.

\section{Concluding remarks}

Different understandings of the "knowledge society" are placed between the understanding of that society as an ideal one strives for, as a real existing society for whose creation and development learning and education have not been particularly emphasised, as well as a real society based on learning and knowledge. After considering numerous relations between the modern world of work and the world of education and training on the basis of the selected characteristics of work, then the phenomena emerged on the basis of global characteristics of work and requirements they address to organised learning opportunities (education

\footnotetext{
35 Predlog standarda usluga karijernog vodenja $i$ savetovanja [Proposal of standards for career guidance and counseling services] (Beograd: Zavod za unapređivanje obrazovanja i vaspitanja, 2017), http://zuov.gov.rs/wp-content/uploads/2018/01/Standardi-KVISPREDLOG.pdf (accessed March 04, 2019), 7-8.

36 Ibidem, 9-17.
} 
and training) and responses these organised opportunities provide, we have formed a certain understanding of the "knowledge society". In our opinion, the "knowledge society" is a real existing society in which we live and at the same time it is an ideal towards which further development of global society is directed. We believe that both emergence and further development of "knowledge society" are based on learning and knowledge, that is, on the changes created by meeting the needs for learning, education and training.

Just as education and training give an extremely important contribution to social changes, in the same way education and training are transformed through the process of meeting the needs the society sets before these two systems. "Knowledge society" requires and creates its own education and training, as shown in the conducted analysis of the selected nine characteristics of the modern world of work (globalisation; breakthrough of ICT; increasing importance of human capital; workplace diversity; ageing of employees; increasing economic activity of women; rising unemployment; changing the concept of security and developing the concept of flexicurity; and changing the career concept), phenomena that accompany them and recorded changes in the field of education and training.

By identifying changes within education and training in the context given, it seems reasonable to us to conclude that those changes included almost all elements of these systems as well as their numerous characteristics. Thus, for example, learning opportunities are becoming more accessible than they used to be and the ways of acquiring professional qualifications are also becoming far more flexible. Requirements for acquiring new knowledge and developing new skills, abilities, competences, attitudes and values have introduced into education and training a real abundance of new contents, starting from key competences and transferable skills to narrow professional competences for performing complex tasks. Education and training are more and more based on outcomes of teaching known in advance and formulated as competences. Development of skills and competences requires different methods, techniques and forms of educational work and it leads to different interrelationships between trainers and participants. Changes can be monitored throughout the design cycle and curriculum and training programme implementation. The quality of the teaching and/or training staff, quality of organisations in which 
programmes are delivered as well as the quality of educational programmes and training programmes are taken into account to a much greater extent. To this end, numerous standards are being set and systems of accreditation, licensing and certification in the field of education and training are being established. New target groups of participants of various ages with their specific needs are entering the processes of education and training. Learning occurs as a very important factor in solving the issue of unemployment, then in accomplishing the flexicurity strategy and career development of each individual.

The significance of the perceived changes both in the world of work and in the world of education and training and in the worlds of individuals fully resembles the significance of changes in the lives of people and communities known through the history of human society when changes occurred in production systems, such as industrial revolutions, scientific and technological revolution and digital revolution. In this paper we have predominantly related the changes typical of the "knowledge society" to the world of work and the world of education as well as to the work-related and professional sphere of life of individuals; however, it is about the changes of all social systems and lives of people as a whole.

\section{References}

A Memorandum on Lifelong Learning. Brussels: Commission of the European Communities, 2000.

John, Arnold et al. Work Psychology: Understanding Human Behaviour in the Workplace. Harlow: Prentice Hall, 2005.

Despotović, Miomir. Razvoj kurikuluma u strućnom obrazovanju [Curriculum Development in Vocational Education]. Beograd: Filozofski fakultet Univerziteta u Beogradu, 2010.

Education 2030: Incheon Declaration and Framework for Action for the implementation of Sustainable Development Goal 4: Ensure inclusive and equitable quality education and promote lifelong learning. UNESDOC Digital Library. 2016 https://unesdoc.unesco.org/ark:/48223/pf0000245656 (accessed December 2, 2019).

ICT specialists in employment, (Eurostat, 2020). https://ec.europa.eu / eurostat/statistics-explained/index.php/ICT_specialists_in_ employment\#General_developments_in_the_demand_for_ICT_sp ecialists (accessed November 06, 2020). 
Jarvis, Peter. "Poučavanje u svijetu koji se menja" [Teaching in a changing world]. In Poućavanje [Teaching], ed. Peter Jarvis, 23-36. Zagreb: Andragoški centar, 2003.

—_. "The Learning Society." In Glossary of Adult Learning in Europe, ed. Paolo Federighi, Willem Bax, Lucien Bosselaers. 21-22. Hamburg: EAEA and UNESCO Institute for Education, 1990.

Key Competences for Lifelong Learning - European Reference Framework. Luxembourg: Office for Official Publications of the European Communities, 2007.

Kovacevic, Milan, and Nebojsa Pavlovic. "Globalization and the Knowledge Society.” Ekonomika 62:4 (2016): 85-94.

Kulić, Radivoje, Miomir Despotović. Uvod u andragogiju [Introduction to Andragogy]. Beograd: Svet knjige, 2004.

Nacionalni akcioni plan zapośljavanja za 2019. godinu [2019 National Employment Action Plan]. Beograd: Ministarstvo za rad, zapošljavanje, boračka i socijalna pitanja; Tim za socijalno uključivanje i smanjenje siromaštva, 2018.

New Skills for New Jobs: Action Now. Brussels: European Commission, 2010.

Noe, Raymond A. Employee Training and Development. New York: McGraw-Hill Irwin, 2010.

Pejatović, Aleksandra. Obuka za odrasle - susret očekivanja i procenjivanja [Adult training - The Encounter of Expectations and Evaluations]. Beograd: Institut za pedagogiju i andragogiju Filozofskog fakulteta Univerziteta u Beogradu. 2019.

Pejatović, Aleksandra, Violeta Orlović Lovren. Zaposlenost $i$ obrazovanje posle pedesete [Employment and Education after Fifty]. Beograd: Institut za pedagogiju i andragogiju Filozofskog fakulteta Univerziteta u Beogradu, Društvo andragoga Srbije, 2014.

Pejatović, Aleksandra, Tamara Kunić. "Obrazovanje odraslih kao faktor ostvarivanja koncepta fleksigurnosti” [Adult education as a factor in realizing (implementing) the concept of flexicurity]. Obrazovanje odraslih 2 (2012): 9-26.

Predlog standarda usluga karijernog vodenja $i$ savetovanja [Proposal of standards for career guidance and counseling services]. Beograd: Zavod za unapređivanje obrazovanja i vaspitanja, 2017. http:/ zuov.gov.rs/wp -content/uploads/2018/01/Standardi-KVIS-PREDLOG.pdf (accessed March 04, 2019). 
The Lisabon Strategy 2000-2010. An analysis an evaluation of the methods used and results achieved. Brussels: European Parliament, 2010.

Unemployment in the EU and the euro area (Eurostat, 2020). https:// ec.europa.eu/eurostat/statistics-explained/index.php/ Unemployment_statistics\#Unemployment_in_the_EU_and_the_eu ro_area (accessed November 06, 2020).

UNESCO Global Network of Learning Cities: guiding documents. Hamburg: UNESCO Institute for Lifelong Learning, 2015. 